San Jose State University

SJSU ScholarWorks

Doctoral Projects

Master's Theses and Graduate Research

Spring 5-2016

\title{
An Exploration of Social Capital among Nurses in the Ambulatory Setting
}

Anna Lutz

California State University, Northern California Consortium Doctor of Nursing Practice

Tamara McKinnon

San Jose State University

Follow this and additional works at: https://scholarworks.sjsu.edu/etd_doctoral

Part of the Nursing Administration Commons, and the Public Health and Community Nursing Commons

\section{Recommended Citation}

Lutz, Anna and McKinnon, Tamara, "An Exploration of Social Capital among Nurses in the Ambulatory Setting" (2016). Doctoral Projects. 34.

DOI: https://doi.org/10.31979/etd.h7ve-xskq

https://scholarworks.sjsu.edu/etd_doctoral/34

This Doctoral Project is brought to you for free and open access by the Master's Theses and Graduate Research at SJSU ScholarWorks. It has been accepted for inclusion in Doctoral Projects by an authorized administrator of SJSU ScholarWorks. For more information, please contact scholarworks@sjsu.edu. 


\section{APPROVED \\ For the California State University, Northern Consortium Doctor of Nursing Practice:}

We, the undersigned, certify that the project of the following student meets the required standards of scholarship, format, and style of the university and the student's graduate degree program for the awarding of the master's degree.
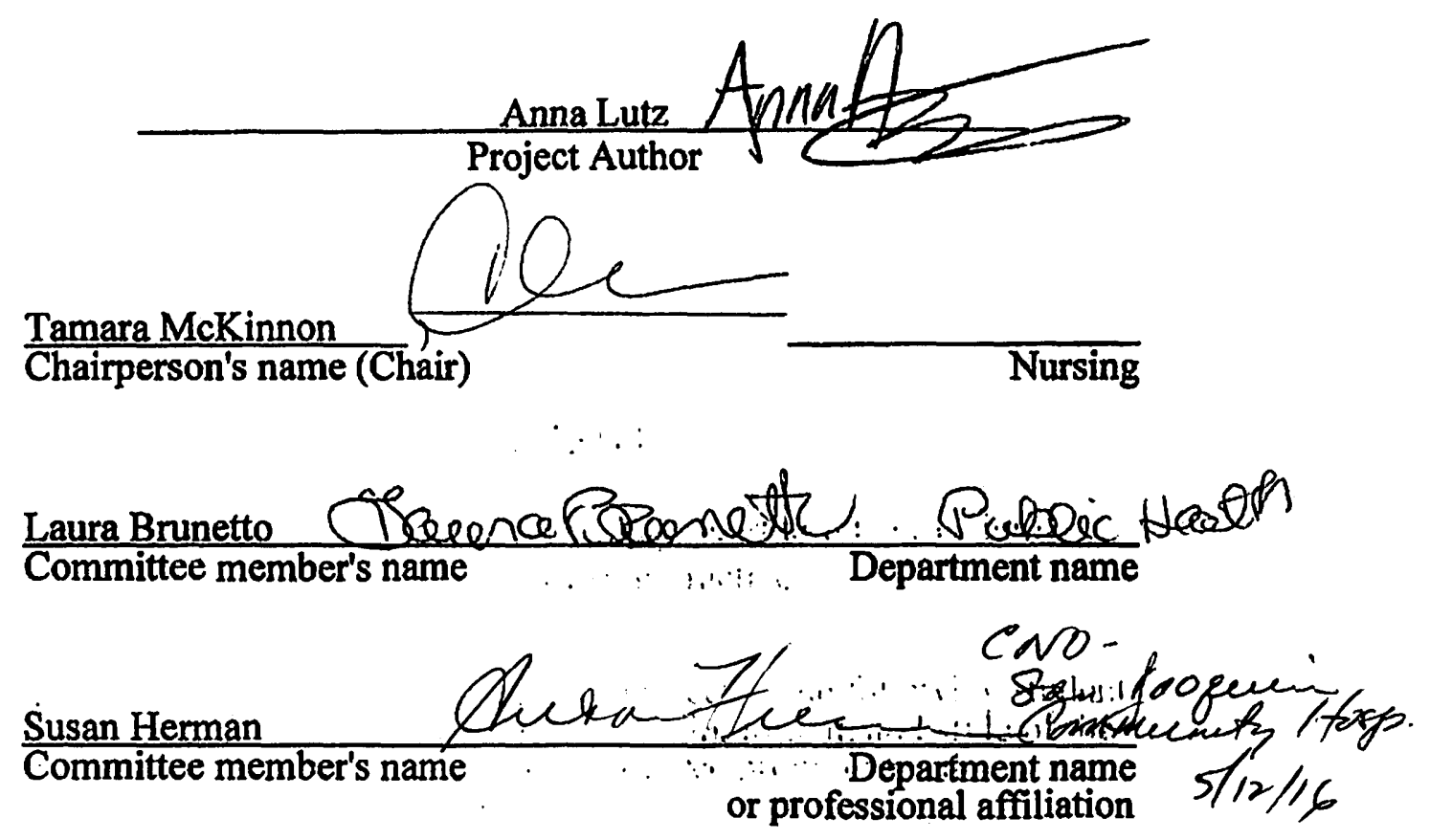


\section{AUTHORIZATION FOR REPRODUCTION OF DOCTORAL PROJECT}

I grant permission for the reproduction of this project in part or in its entirety without further authorization from me, on the condition that the person or agency requesting reproduction absorbs the cost and provides proper acknowledgment of authorship.

Permission to reproduce this project in part or in its entirety must be obtained from me.

Signature of project author: 
Running head: EXPLORATION OF SOCIAL CAPITAL IN NURSES

An Exploration of Social Capital among Nurses in the Ambulatory Setting

First Author Anna Lutz, RN, MSN, DNP(c) (corresponding author)

California State University, Nursing Consortium

5241 N Maple Ave, Fresno, CA 93740

Anna.k.lutz@gmail.com

831-539-6674

Second Author Tamara McKinnon, RN, DNP

San Jose State University

1 Washington Sq, San Jose, CA 95192 


\begin{abstract}
Bullying and lateral violence are a sadly, common phenomena among nurses. While this issue has been examined within the inpatient, acute setting, it has not been widely researched in the ambulatory setting. This concept is usually looked at from a negative standpoint, looking at the levels of lateral violence. The purpose of this research study was done to explore the levels of social capital, also known as positive peer support, among nurses in the ambulatory setting. The participants of the study were 39 registered nurses from a public health department and an embedded care management department. The tool used was an 18 question survey that was evaluated on a 5 point Likert scale. The results were generally positive showing that the nurses had trust and confidence in their organization, management, and coworkers, but there were also several statistically significant results that showed difference in experience levels of the nurses and their responses and also differences between work location and their responses.
\end{abstract}

Keywords: Lateral Violence, Ambulatory Nurses, Social Capital, Bullying 
An Exploration of Social Capital Among Nurses in the Ambulatory Setting

Nursing is known as a caring, compassionate profession. It is also considered one of the most trusted professions of all time, recently reflected in a Gallup poll (2013) where nurses were rated number one, over grade school teachers and pharmacists. Even with this history, bullying is ever present in nursing. Bullying is defined as "use of superior strength or influence to intimidate (someone), typically to force him or her to do what one wants" (Oxford Dictionaries, 2015). Most people do not often associate nursing and bullying yet nearly $57 \%$ of nurses' report verbally abuse by another staff member (American Nurses Association, ANA, 2001). While it is hard to quantify the exact number of nurses leaving the field due to hostile work environments, studies indicate that turnover rates among nurses are between $22.6 \%$ and $60 \%$ (VanWyngeeren, 2009). Across the literature, bullying in the healthcare field is often equated with lateral violence, meaning violence from one staff person to another.

The Center for American Nurses (2008) released a powerful position statement on lateral violence (violence toward other nurses) within nursing, including detailed definitions of different ways in which this can be exhibited. The organization defines lateral violence as "nurse to nurse aggression" and "workplace bullying is repeated inappropriate behavior, direct or indirect, whether verbal, physical or otherwise, conducted by one or more persons against another or others, at the place of work". There are numerous studies looking at this phenomenon in the acute care setting, however there is little research to date studying the outpatient setting. Some areas not yet addressed include peer to peer interaction in a non-acute nursing setting across the nursing continuum, if bullying is a problem in this population, and consideration of some ways in which this phenomenon can be positively mitigated. One possible way to mitigate lateral 
violence would be through the use of social capital. Social capital, defined as "the networks of relationships among people who live and work in a particular society, enabling that society to function effectively" (Oxford Dictionaries, 2015). This is an important topic to explore, not only because more nursing jobs are moving into the non-acute setting, but additionally, most nurses do not have an understanding of what that job environment is like before they become employed in that setting (Swan, 2007). Just as in the acute care setting, these positions appear to have high burn out and as Doctorate of Nursing Professionals (DNP) professionals; it is our responsibility to help mitigate this problem. Therefore, what are the levels of social capital of Public Health Nurses (PHNs) working in the non-acute environment?

\section{Literature Review}

A review of the literature found that Smith et al. (2011) conducted a correlational, quantitative study examining the frequency of bullying towards 853 perioperative nurses working in the United States and the impact on patient outcomes. Eighty five percent of the participants were female with the majority, forty three percent, between 50-59 years old. Results indicated an association between organizational predictors of bullying and the 5 "surgical nevers: which are: surgery on the wrong patient, surgery on the wrong site, the wrong surgical procedure, retained surgical item, and intraoperative or immediate postoperative death of a healthy patient, and a negative statistical significance between consequences of bullying and the 5 surgical nevers. In the author's opinion, this study continues to show the need for education on and organizational change towards bullying and lateral violence as it not only effects the individual but also patient outcomes, confirming the importance of social capital in mitigating lateral violence and improving patient outcomes. This study had a very large sample size, but is limited by the fact that the tool has not been validated, and it is limited to a very specific 
category of potential bullying. In addition to this study, there are other studies showing the prevalence of bullying and lateral violence.

Using a descriptive, quantitative design, Vessey et al. (2009) surveyed 303 acute care nurses in the US working in acute care units to identify the prevalence of bullying among nursing peers and physicians. Participants were Registered Nurses (RNs) who ranged between 23 to 68 years with 289 females and 14 males. Two hundred and fifty eight (85\%) of the participants were Caucasian. The data showed that the medical surgical unit was the most common site of bullying and that higher level, or more senior nurses were most often the ones doing the bullying. Findings suggest that RNs are particularly vulnerable to being bullied and administrative staff need to be acutely aware of this in order to intervene when possible. This author recommends research could be done exploring why some nurses do not leave, even after they have been targeted for bullying. This study was well done and grounded in research, but it could have had a bigger sample size and a broader spectrum, such as beyond acute care settings. In looking at lateral violence there is a tendency to associate burnout to lateral violence as well, but what positive elements fighting lateral violence could reduce burnout, other then just reducing bullying?

A quantitative study done in Peru sought the answer to the question: is there a sociodemographic or occupational characteristic that leads to increased burnout (Ayala, 2013)? Ninety three nurses and nursing assistants from medical surgical units and critical care units in Peru responded to this study. 88 were female, five were male and no racial information was provided. The study was done using a socio-demographic/occupational questionnaire and a tool called the Maslach Burnout Inventory The results showed that increased age, having children, and being divorced were associated with higher burnout rates, as was working in the ER or ICU 
in comparison to the recovery room. The results were measured through statistical calculations. By looking at positive elements that can be implemented to decrease literal violence and increase social capital for a more positive work environment, this study has the potential to guide the efforts of managers and employers. While the study provided valuable information, it would be helpful to see the results duplicated in a study done in the United States. This study used a valid and reliable tool and provided meaningful data (Ayala, 2013). If social capital were used as a way to mitigate burnout and lateral violence, a useful model to compare social capital to would be structural empowerment.

Very similar to the concept of social capital is the concept of structural empowerment, which is focusing on the changes that can be made to the structure or organization to positively impact an individual (Moore, 2014). A quantitative survey interviewing 525 nurses in Ontario, Canada, by Laschinger (2014), sought to find the answer to the research question: is there a correlation between the structural empowerment of a nursing unit and that unit's work efficiency. The majority of these nurses worked in medical surgical units and had a mean age of 42 , but no gender or racial characteristics were shared. The data was gathered through standardized questionnaires. Results showed a positive correlation between the structural empowerment of the unit and nursing perceptions of quality of care provided. This study continues to support the idea that unit trust and bonding lead to improved quality and outcomes. There is so much room for performance improvement when it comes to managing nursing units with business, quality, and efficiency in mind. In the author's opinion there is room for more participants and a broader spectrum of participants, but it was not a small study as there were more than 500 participants.

A quantitative, cross-sectional survey looking at social determinants of weight loss shows the value of the social ecological model as a theoretical framework (Blanchard, 2005). There 
were 6739 respondents to this mail out survey. Most participants were aged 48-51 years old with 63 percent being female and 70 percent being Caucasian. The study asked is there a correlation between social determinants and weight status? The results then showed that higher social support and self-efficacy were significant for a positive correlation with physical activity. This study showed the importance of focusing on the social factors surrounding someone's weight status. This was a large study with almost 6000 participants, but being that it was cross sectional this data cannot be proved as cause and effect. What this study does show is the impact social powers have on one's well being.

In looking at the existing literature surrounding bullying, nursing retention, and social capital there are definite gaps in the literature. First, there is a shortage of research examining this phenomenon in the outpatient setting. Secondly, the research involving social capital specifically, as opposed to bullying, is very limited. In looking at these combinations, there is an

opportunity for new research and study. Given this gap in the research, the level of perceived social capital within outpatient Public Health Nursing (PHNs), is being investigated further. The research project is a pilot study with the goal of showing a need for a correlational study between social capital and nursing retention. The specific research question is what are the levels of social capital among nurses in small to moderate size outpatient nursing organizations in Northern California?

\section{Method}

\section{Data Collection, Instruments, and Participants}

The researcher investigated the level of social capital among PHNs in the outpatient, public health setting. In order to do this within a timely fashion for the constraints of the DNP timeline, the researcher used a survey tool. In particular, this survey would be likened to the 
organizational social capital assessment (Lundstrom, 2014). With the use of this survey to gather data, this study falls into the category of a descriptive, quantitative study. The researcher converted the questions into a form usable within a platform like survey monkey and delivered this survey via that method. The author was then able to gather the anonymous data directly from their website. The data was collected online between October 10, 2015 to December 10, 2015 via anonymous online surveys and reviewed by the researcher.

\section{Risks and Consents}

Both organizations participating will be given a copy of the completed project prior to any journal submission. This study has no potential risk to any patient as only nurses are subjects. The study will pose no legal, economic, or physical risk to any subject. Since the study is online and anonymity will be maintained, the social and psychological risks are very minimal.

The management of risk will be minimal as there is no physical risk involved for the participants. Confidentiality will be maintained as the survey system does not save any names associated with the survey answers. All subject responses will be maintained in a password protected system. Upon completion of the study and analysis, all data will be permanently deleted from the database. Consent from subjects will be made clear in the initial page of the online survey by stating "By completing and returning this survey, the respondent is voluntarily consenting to becoming a research subject". The project will take place among RNs working within a Northern California Public Health Department and a Northern California Care Management Company.

The research itself will be minimal in cost. The survey tool would be a maximum of $\$ 80$. The only other cost that would be incurred is a statistician which should not go above $\$ 500$. 


\section{Results}

One of the goals of this study was to have 20-40 participants in the study. Within the two month time period for data collection, 39 complete surveys came in. Of these completed surveys, three were male registered nurses and 36 were female registered nurses. The age of the participants were dispersed in roughly a bell shaped curve. Four of the staff were between the age of 20 and 30, eight between 31 and 40, 11 between 41 and 50, 10 between 51 and 60, and six over the age of 60 (Figure 1).

What is your age?

\section{Answer Options}

20-30

$31-40$

41-50

$51-60$

$60+$

Figure 1

$\begin{array}{cc}\begin{array}{c}\text { Response } \\ \text { Percent }\end{array} & \begin{array}{c}\text { Response } \\ \text { Count }\end{array} \\ 10.3 \% & 4 \\ 20.5 \% & 8 \\ 28.2 \% & 11 \\ 25.6 \% & 10 \\ 15.4 \% & 6\end{array}$

One individual indicated that they considered their place of employment to be a practice site, 32 stated they worked in public health, 2 viewed their work to be in PCP offices, and 4 in an undefined category. Lastly, 11 nurses indicated they had 5 or less years of experience, 6 have 6 to 10 years of experience, 10 with 11 to 20 years, 9 with 21-30 years of experience, and 3 with 30 or more years of experience (Figure 2).

\begin{tabular}{l|cc} 
How many years of experience in nursing do you have? & & \\
Answer Options & $\begin{array}{c}\text { Response } \\
\text { Percent }\end{array}$ & $\begin{array}{c}\text { Response } \\
\text { Count }\end{array}$ \\
0-5 years & $28.2 \%$ & 11 \\
6-10 years & $15.4 \%$ & 6 \\
$11-20$ years & $25.6 \%$ & 10 \\
$21-30$ years & $23.1 \%$ & 9 \\
$30+$ years & $7.7 \%$ & 3
\end{tabular}


The survey itself consisted of 18 questions all with a 1 to 5 scale for responses with 1 being strongly disagreeing with the statement, 2 somewhat disagreeing, 3 neutral, 4 somewhat agree, and 5 strongly agree. On most questions, the majority of the answers strongly trended to the positive (Figure 3).

\begin{tabular}{|c|c|c|c|c|c|c|}
\hline \# & Questions 1-10, 12-14, and 16-18 & $\underline{1}$ & $\underline{\mathbf{2}}$ & $\underline{\mathbf{3}}$ & $\underline{4}$ & $\underline{5}$ \\
\hline 1 & $\begin{array}{l}\text { People in each of these groups } \\
\text { communicate with you about } \\
\text { patients with chronic disease }\end{array}$ & 2 & 4 & 8 & 16 & 9 \\
\hline 2 & $\begin{array}{l}\text { Do people in these groups } \\
\text { communicate with you in a timely } \\
\text { way about patients with chronic } \\
\text { diseases? }\end{array}$ & 4 & 2 & $\mathbf{1 0}$ & 20 & 3 \\
\hline 3 & $\begin{array}{l}\text { Do people in these groups } \\
\text { communicate with you accurately } \\
\text { about patients with chronic } \\
\text { diseases? }\end{array}$ & 3 & 5 & 11 & 16 & 4 \\
\hline 4 & $\begin{array}{l}\text { When problems occur with patients } \\
\text { with chronic disease, do the people } \\
\text { in these groups blame others? }\end{array}$ & 10 & 5 & 12 & 8 & 4 \\
\hline 5 & $\begin{array}{l}\text { How much do people in these } \\
\text { groups share your goals regarding } \\
\text { patients with chronic diseases? }\end{array}$ & $\mathbf{1}$ & 2 & 12 & 19 & 5 \\
\hline
\end{tabular}




\begin{tabular}{|c|c|c|c|c|c|c|}
\hline 6 & $\begin{array}{l}\text { How much do people in each of } \\
\text { these groups know about the work } \\
\text { you do with patients with chronic } \\
\text { conditions? }\end{array}$ & 4 & 7 & 11 & 15 & 2 \\
\hline 7 & $\begin{array}{l}\text { How much do people in these } \\
\text { groups respect the work you do } \\
\text { with patients with chronic } \\
\text { conditions }\end{array}$ & 3 & 4 & 13 & 12 & 7 \\
\hline 8 & $\begin{array}{l}\text { You can trust the information } \\
\text { coming from management }\end{array}$ & 2 & 6 & 7 & 12 & 12 \\
\hline 9 & $\begin{array}{l}\text { The management trusts that the } \\
\text { employees do their work well }\end{array}$ & 3 & 3 & 7 & 14 & 12 \\
\hline 10 & $\begin{array}{l}\text { The employees do in general trust } \\
\text { each other }\end{array}$ & $\mathbf{1}$ & $\mathbf{0}$ & 5 & 18 & 15 \\
\hline 12 & $\begin{array}{l}\text { I am able to express my views and } \\
\text { feelings to my colleagues }\end{array}$ & 1 & 3 & 2 & 18 & 15 \\
\hline 13 & $\begin{array}{l}\text { Conflicts between employees are } \\
\text { resolved fairly for everybody } \\
\text { involved }\end{array}$ & 1 & 1 & 11 & 17 & 9 \\
\hline 14 & Work is distributed fairly & 3 & 5 & 7 & 14 & 10 \\
\hline 16 & $\begin{array}{l}\text { Among us everybody is involved in } \\
\text { decisions regarding changes }\end{array}$ & 2 & 7 & 10 & 14 & 5 \\
\hline
\end{tabular}




\begin{tabular}{|c|c|c|c|c|c|c|}
\hline 17 & $\begin{array}{l}\text { If I forget something then one of } \\
\text { my colleagues will take care of it } \\
\text { for me }\end{array}$ & 5 & 5 & 7 & 15 & 7 \\
\hline \multirow[t]{3}{*}{18} & $\begin{array}{l}\text { We have a good cooperation } \\
\text { between workgroups }\end{array}$ & 1 & 3 & 7 & 16 & 12 \\
\hline & & 2.875 & 3.875 & 8.75 & 15.25 & 8.1875 \\
\hline & Questions 11 and 15 & $7 \%$ & $10 \%$ & $21 \%$ & $38 \%$ & $21 \%$ \\
\hline 15 & $\begin{array}{l}\text { I do not have a large degree of } \\
\text { influence over my work }\end{array}$ & 4 & 11 & 6 & 14 & 3 \\
\hline \multirow[t]{3}{*}{11} & $\begin{array}{l}\text { Do employees withhold } \\
\text { information from each other? }\end{array}$ & 14 & 9 & 9 & 4 & 3 \\
\hline & & 9 & 10 & 7.5 & 9 & 3 \\
\hline & & $23 \%$ & $27 \%$ & $19 \%$ & $23 \%$ & $8 \%$ \\
\hline
\end{tabular}

Figure 3

\begin{tabular}{|l|l|l|l|l|}
\hline \multicolumn{5}{|c|}{ Combined Averages } \\
\hline 2.492063 & 4.7460317 & 7.900794 & 14.261905 & 9.448413 \\
& & & & \\
\hline
\end{tabular}

Figure 4

In looking at the responses, the majority of the nurses were overwhelmingly positive in their answers with a combined average of 23.7 respondents responding with either somewhat agree or strongly agree in terms of the positives of trust, collaboration, and teamwork. On the 
other side, only an average of 7.24 survey participants had negative responses to these organizational social capital questions. Of particular importance to note though, 17 survey responses indicated that they felt they did not have a great deal of influence over their work. Communication and shared interests were rated very highly though. An average of 25 nurses indicated that there was good communication on patients and 24 said there were shared goals on patients.

By further evaluating the data based on difference of job location, namely a practice location versus a public health location, there were five questions that showed statistically significant differences in the responses. However, of particular note in figure 5 is that some of the response favored public health and some of the responses, primarily knowledge of chronic conditions, favored the practice setting. Indicating that there may be opportunity for valuable cross training or lessons learned from other work settings.

\begin{tabular}{|l|l|l|}
\hline Practice versus Public Health & Practice & Public \\
& Health \\
\hline Responses & 7 & 32 \\
\hline Median Age & $41-50$ & $51-60$ \\
\hline Experience & $<10$ years & $11-20$ \\
\hline for me & expeirence & years \\
\hline Work is distributed fairly & 2.43 & 3.56 \\
\hline Do employees withhold information from each other? & 2.86 & 3.75 \\
\hline
\end{tabular}




\begin{tabular}{|l|l|l|}
\hline $\begin{array}{l}\text { How much do people in these groups share your goals regarding } \\
\text { patients with chronic diseases? }\end{array}$ & 4.14 & 3.53 \\
\hline How much do people in each of these groups know about the work & 4.57 & 2.97 \\
you do with patients with chronic conditions? & & \\
\hline
\end{tabular}

Figure 5

The data was also evaluated based on differences of experience level (figure 6). This again provided responses to five of the questions that were statistically significant. Two of the responses from nurses with less than ten years of experience were particularly valuable. These responses, the first discussing colleagues helping each other and the second discussing being able to express your views to colleagues, both seem to reinforce the old term of "nurses eating their young". While this is something the researcher had hoped to not find, it was also valuable to find that those RNs with less experience did not score lower than RNs with more experience on the majority of the survey questions asked.

\begin{tabular}{|l|l|l|}
\hline Expereince Differences & $>10$ years & $\begin{array}{l}<10 \\
\text { years }\end{array}$ \\
\hline Responses & 22 & 17 \\
\hline Median Age & $51-60$ & $31-40$ \\
\hline Experience & $11-20$ & $0-5$ \\
\hline $\begin{array}{l}\text { If I forget something then one of my colleagues will take care of it } \\
\text { for me }\end{array}$ & 3.91 & years \\
\hline
\end{tabular}




\begin{tabular}{|l|l|l|}
\hline I am able to express my views and feelings to my colleagues & 4.09 & 2.94 \\
\hline How much do people in each of these groups know about the work & 2.91 & 3.52 \\
you do with patients with chronic conditions? & & \\
\hline When problems occur with patients with chronic disease, do the \\
people in these groups blame others? & 2.41 & 3.24 \\
\hline $\begin{array}{l}\text { Do people in these groups communicate with you in a timely way } \\
\text { about patients with chronic diseases? }\end{array}$ & 3.14 & 3.76 \\
\hline
\end{tabular}

Figure 6

Discussion and Recommendations

Nurses are often known for both being very particular about their work and processes and for "eating their young" or being bullies. The data gathered here in this study indicates that this might not always be the case among nurses or at least not universally across all settings. This study starts laying the foundation for future studies into organizational social capital. Hospitals, organizations, management, and teams are often looking for new ways to evaluate their staff and to see if there is anything they can do better as management or an organization to support the staff, and in this case the nurses, more fully. This researcher was pleased with the number of survey responses, but one of the weaknesses of this study was that it was still relatively small and that it was a data gathering pilot. Future researchers could use this study as a catalyst for more research that could even possibly show correlations between high social capital rates and low turnover rates. Additionally, by looking at different types of nursing jobs or locations, trends could be identified and the high performing jobs or locations could be modeled to help improve those with low social capital rates. Even simply emphasizing cross training could show levels of 
improvement in social capital. Hopefully, by beginning to use tools like this and implementing the findings into practice, nursing job satisfaction will increase, turnover decrease, bullying decrease, and positive patient outcomes increase. 


\section{References}

American Nurses Association. (2011). Lateral violence and bullying in nursing. Retrieved from http://www.nursingworld.org/Mobile/Nursing-Factsheets/lateral-violence-and-bullyingin-nursing.html

Ayala, E. \& Carnero, C. (2013). Determinants of burnout in acute and critical care military nursing personnel: a cross-sectional study from Peru. Retrieved from http://www.ncbi.nlm.nih.gov/pubmed/23342152

Blanchard, C. et al. (2005). Social ecological correlates of physical activity in normal weight, overweight, and obese individuals. International Journal of Obesity. 29. Retrieved from http://www.nature.com/ijo/journal/v29/n6/full/0802927a.html

Bullying. (2015). In Oxford Dictionaries Online. http://www.oxforddictionaries.com/

Center for American Nurses. (2008). Lateral violence and bullying in the workplace. Retrieved from http://www.mc.vanderbilt.edu/root/pdfs/nursing/center_lateral_violence_and_bullying_p osition_statement_from_center_for_american_nurses.pdf

Gallup. (2013). Honesty/ethics in professions. Retrieved from http://www.gallup.com/poll/1654/honesty-ethics-professions.aspx

Laschinger, H. \& Read, E. (2014). The influence of nursing unit empowerment and social capital on unit effectiveness and nurse perceptions of patient care quality. The Journal of Nursing Administration. 6(44). Retrieved from EbscoHost.

Lundstrom SL, Edwards K, Knudsen TB, Larsen PV, Reventlow S, Sondergaard J: Relational coordination and organizational social capital association with characteristics of general practice. Int J Fam Med. 2014, 2014: 618435. 
Moore, S. (2014). Structural empowerment and the Magnet Model: A perfect fit. Retrieved from https://americannursetoday.com/structural-empowerment-magnet-model-perfect-fit/

Roseter, R. (2014). Nursing shortage fact sheet. American Association of Colleges of Nursing. Retrieved from http://www.aacn.nche.edu/media-relations/NrsgShortageFS.pdf

Smith, J., Hess, D., Black, R., \& Mohr, D. (2011). Bullying in the nursing workplace: A study of perioperative nurses. Retrieved from http://media.proquest.com/media/pq/classic/doc/2524265761/fmt/ai/rep/NPDF?_s=UzDk 2Z4NJjD1QtxyDevw2Z5V8\%2BM\%3D

Social Capital. (2015). In Oxford Dictionaries Online. http://www.oxforddictionaries.com/ Swan, Beth Ann. (2007). Transitioning for acute care to ambulatory care. Nursing Economics 25(2). Retrieved from http://jdc.jefferson.edu/cgi/viewcontent.cgi?article=1013\&context=nursfp VanWyngeeren, K. (2015). Increasing new graduate nurse retention from a student nurse perspective. Retrieved from http://rnjournal.com/journal-of-nursing/increasing-newgraduate-nurse-retention-from-a-student-nurse-perspective

Vessey, J., et. Al. (2009). Bullying of staff registered nurses in the workplace: a preliminary study for developing personal and organizational strategies for the transformation of hostile to healthy workplace environments. Journal of Professional Nursing. 25(5). Retrieved from Elsevier. 